\title{
Chapter 2 \\ By design, survival and recognition: \\ Exploring the contemporary significance of monuments in South Africa
}

\section{Anitra Nettleton}




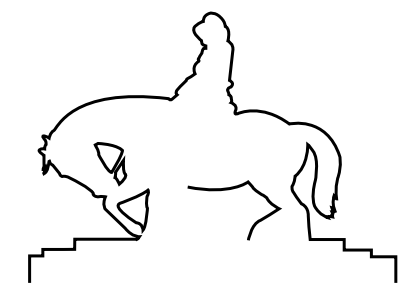

$\mathbf{T}^{\mathrm{n}}$ the past 23 years, since the first democratic elections saw the ascendancy of the African National Congress to power in the Republic of South Africa, there has been a continuous, if somewhat muffled history of both the destruction and the erection of monuments that inhabit the public domain. With a constitutional democracy in place, South Africa could be said to have the ideal platform for the formation of a public domain, a space of open debate in which different views could be aired and compared. This public sphere, extrapolating from Habermas (1989), could possibly be stretched contain elements of both western and indigenous African principles of debate and deference to majority decisions. Yet, over the last three years tensions around the status of public monuments have, as it were, erupted from a volcanic substructure of reaction to colonialism and apartheid, resulting in a wide range of shock waves across the republic's rather fragile politico-cultural landscape.

In this chapter, I take a deeper look at the whole question of why monuments are such a focus of attention, for their makers, their audiences and their detractors/destroyers. Of all the fixed forms of visual art that appeared in the public domain in the past, with the exception of architecture, monuments have been the most visible and accessible. That, today, many monuments from the past are dwarfed in size and prominence by the rampant billboards and banners of commercial advertising, seems not to have diminished the symbolic importance attached to their presence as things that commemorate, or otherwise remind, their viewers of the past. For monuments are not 
merely more public sculptures, they are, as Reynolds (1996) succinctly puts it, 'embodiments and symbols of [our] traditions and values'.

In what follows, I explore what constitutes the significance of a monument, from historical circumstances to the contemporary domain. Because both the word 'monument' and the current secular and civic practices (as opposed to religious and royal/elite/ autocratic ones) of commemoration to which it refers, have largely (although by no means exclusively) been located within western cultural traditions and practices, it is important to unpack their origins and ostensible meanings to enable a forthright assessment of their relevance in a postcolonial and supposedly decolonising state. My argument, to some extent, derives from Alois Riegl's (1982) tripartite definition of monuments, originally published in 1903, but only translated into English in 1982. Riegl's concern was largely to establish how cultural and historical values of objects can be defined in relation to issues of preservation - so that anything at any scale or in any context may become a venerable 'monument' (Riegl 1982). My endeavour differs in that I want to understand why public, large-scale civic monuments having come into being particularly in the South African historical landscape, either live on or perish in relation to political and social imperatives. In other words, what makes their significance relevant or not?

\section{Defining the field}

The Shorter Oxford English Dictionary (1964) definitions of the term "monument" are instructive in helping to circumscribe what may or may not be considered such. The word itself derives from the Latin monumentum: "Latin Monere = remind, and suffix -ment - result or means of visible action", and I have picked out from a longer list the three definitions most relevant to my discussion: 
1. Anything that, by its survival, commemorates a person, action, period or event.

2. A structure, edifice or erection intended to commemorate a notable person, action or event.

3. A structure of stone or other material erected over the grave or in church etc in memory of the dead.

4. A carved figure, effigy. (Oxford English Dictionary 1964, 1278)

These definitions encompass both the kinds of things that may be considered monuments, and their function as memorials that commemorate, and thus implicate notions of memory. Thus the relationship between monuments and memorials becomes an important factor in understanding the symbolic domain in which monuments operate. Clearly a memorial is something intended to "remind" the person paying attention, to call something past into the present, and can take a number of forms including a memorial service, a memorial action, a commemorative bequest. The Oxford English Dictionary's definitions of "memorial", in its simple formulation, is "sign of remembrance, memorial, monument" (Oxford English Dictionary 1964, 1232). But it then continues to outline the following substrata of "memorial":

1. Remembrance, recollection; (a person's) memory or power of recollection.

2. A memorial act; an act of commemoration

3. A thing, as a monument, a custom, etc., by which the memory of a person, thing, or event is preserved.

4. A record, a chronicle; esp. in pl., memoirs. (Oxford English Dictionary 1964, 1232)

It is a common contention that the memorial act, that is, the act of remembering, and so the remembrance, on one hand, and the thing, custom and/or record on the other are inextricably linked in closing the symbolic circle which makes the monument relevant in any context. 
Once the thing is no longer part of an active form of remembering, it cannot act as a monument, or even as a memorial. The memorial aspect of monuments is reflected in the fact that many monuments are called memorials, as in the German denkmal, the Nederlands gedenkteken and the isiZulu term isikhumbuzo.

However, while it can be argued that all monuments can function as memorials in that they are reminders, sometimes embedded in commemoration that is proud and desired, at other times unwanted and injurious, it cannot be said that all memorials are monuments. Furthermore, for a monument to perform its memorial function, the memories it invokes/evokes would have to have some affirmative value, as, for example, in marking pride in those who fought for a (just?) cause and died in the process. It could also be argued that memorials that are not monuments might be preferable to the monumental structures that litter our actual and cultural landscapes.

The difference between a memorial and a monument can be clearly articulated by dissecting the adjectival form of the word monument, i.e. "monumental". In its simplest application, something that serves as a monument may be termed "monumental", but the more usual, metaphorical and colloquial use of the term, as in "monumental blunder", meaning "massive and permanent, extremely great, stupendous" (Oxford English Dictionary 1964, 1278) is the one most commonly used in describing the things made to act as monuments. The fact that monuments are associated with size, grandeur and longevity or permanence, as memorials to persons and deeds deemed worthy of remembrance, suggests that the erection of monuments is always based in an intention to aim for immortality. It is also always based on assumptions that the values of those erecting the monuments will remain valid for succeeding generations, in spite of the fact that the destruction/removal of monuments - a form of iconoclasm (Gamboni 1997; Grant 2001; Freedberg 1989, 2012) - offers continuous evidence that they do not. 


\section{Monuments by design}

The Oxford English Dictionary definitions numbers 2-3 cited above suggest that monuments that are made as such, are designed as mnemonic devices, erected to last and commemorate persons and events. Such monuments are moreover generally associated with public spaces, and, although some may be privately funded, the majority are funded through the mechanisms of the state or the polity, as statements of history. A monument by design must be VISIBLE from time of production: it must be intended to uphold a particular construction of memory in the public eye. If, as Nora (1989) suggests, history is written in order to enable us to forget, because public history is the repository of memory, then, presumably monuments, as public memorials, enable the same kind of forgetting and remembering. Nora offers the following differentiation between memory and history, which gives this differentiation more eloquently:

Memory is life, borne by living societies founded in its name. It remains in permanent evolution, open to the dialectics of remembering and forgetting, unconscious of its successive deformation, vulnerable to manipulation and appropriation, susceptible to being dormant and periodically revived. History, on the other hand, is the reconstruction, always problematic and incomplete, of what is no longer. (Nora 1989, 7)

Yet it is questionable whether remembering events and persons depicted in figurative monuments is possible without verbal clues, or commemorative events and performances - in other words monuments as memorials are dependent on forms of history, and are therefore only as significant as the possible associations that can be made between them and known persons and/or events. It is possibly the enforced performance of obsequy demanded by larger than lifesize and imposing figures of hated characters such as the colonial master Cecil John Rhodes that make them so distasteful to those who have been oppressed. 
Historically, monumental public civic sculptures and memorial architectural structures intended to last over centuries were only occasionally, and quite exceptionally, erected in indigenous African cultures South of the Sahara. In 'the west', however, they have a very long history going back to Ancient Greece. In Egypt, Nubia, Axum, India and Asia most monumental structures and sculptures were religious and tied to a theistic monarchic polity rather than a nominally civic one. Apart from the large multitude of massive sculptures to deities and Pharaohs that littered the ancient Egyptian and Nubian landscape, there were no other figurative large-scale (life-size or above) stone or bronze sculptures made by African artists that were equivalent in size or propagandistic function to the civic sculptures of Roman emperors, such as the Augustus of the Prima Porta the Colossus of Constantine, or the equestrian statue of Marcus Aurelius (Brilliant, 1974), all of which are still used as models for monumental bronze sculptures, even those in Africa. The tradition of commemorative, naturalistic and identifiable individual portraits being used as memorials/monuments, can be traced back to the ancient Roman Republic, with a provincial offshoot in the Fayum portraits in Ptolemaic Egypt and similar small forms dating much later in Ghana and possibly Nigeria. The portrait tradition continued through Europe among the aristocracy in tomb effigies, was revived in the Italian Renaissance in contexts that moved out of the burial context, and into the Enlightenment at which point, making monuments becomes part of the public sphere.

Jurgen Habermas (1989) argues that the public sphere emerged in Europe specifically, from a space in which the power of royal elites was advanced and upheld to one constituted by families and their heads, the urban middle classes. The constitution of the public sphere lies in how these private families moved outside and beyond the domestic sphere, with private individuals becoming public citizens. Here work/labour moved from the family compounds into spaces more open to public access and egress and in which debate and reasoned criticism could occur among peers. It was in this open sphere that new monuments could have functioned as memory-markers for secular and non- 
royal events and persons. Yet, the tradition of monument making has remained elitist, driven by political agendas, and almost entirely patriarchal until quite late into the $20^{\text {th }}$ century. Monuments depicting images of men standing high on plinths dominate in Europe and the USA, and, while allegorical group sculptures often include voluptuous female figures, many modelled on Greek originals such as the Nike of Samothrace, they seldom commemorated real-life women. Among the most vaunted memorial forms, equestrian statuary associated with status and power since Ancient Roman times - viz. the sculpture of Marcus Aurelius in Rome - has almost completely excluded women, being used to commemorate male leaders everywhere. It has been employed in similar ways in many (small scale) examples of African sculpture such as the Djenné terracotta horsemen (De Grunne 2014) and the horsemen of Yoruba house posts (Blier 1998). The power dynamics at play here are of course based in the fact that there have been few women in the past with sufficient power to hand to make such monuments either necessary or desirable.

The image of Cecil John Rhodes, in a prominent position on the campus of the University of Cape Town (UCT), belonged to a long line of images of seated male potentates, but possibly owed its closest debt to Auguste Rodin's sculpture called The Thinker. Its naturalistic rendering of anatomy, idealised form, scale and material all sit firmly within the western tradition of monumentality, even though its emotive exaggerations of pose suggest a debt to early modernism. This, nevertheless entirely predictable and almost bankrupt tradition of naturalistic sculpture was exported across the world in the form of colonial monuments followed by independence monuments, the latter often in the very tired style of social realism favoured in the old 'communist bloc', and now prevalent in the postcolonial industry of monument making by Chinese and Korean artists.

That the many colonial and some postcolonial monuments, made and installed by design have suffered, and are still now suffering similar fates of dismantling and deposition as that meted out to the statue of 
Rhodes, or complete demolition (which fate is best, depends on one's point of view) bears out the idea that monuments by design are most likely temporary and most certainly not eternal. Such monuments' attempted imposition of values is replaced by their evocation of shared histories of oppression and exploitation, as is abundantly clear from the furore that surrounded the \#RhodesMustFall campaign. The triumphalist messages the old monuments were intended to convey to their original white audiences (as though the black people who encountered them did not see them) can no longer be tolerated in a changed cultural and political space. Some of this intolerance may be related to an argument mounted by Steven Knapp (1989) in which he posits that collective memory, whether it has any actual relationship to actual events or not, in some senses coerces individuals to acknowledge their culpability in the remembered events. Following this logic, such statues should be as discomforting for the descendants of white settlers (and new white settlers) as they are for the present generations of black citizens.

\section{Monuments by survival: a matter of heritage}

In the South African landscape there are innumerable monuments that have survived from the past. Many of these, like the Rhodes Memorial on Signal Hill above the UCT campus, are monuments that were built in the colonial and later apartheid eras. The Rhodes Memorial, because it is so far outside the normal passage of foot traffic of ordinary Cape Town residents or UCT students, has gone relatively unremarked. However, a monument such as the Kruger Monument in Church Square, in the centre of Pretoria/Tshwane city, while it still survives, has been moved, defended, defaced and restored many times and imprisoned in steel fences and rolls of razor wire when protest action is anticipated (Figure 2.1). It corresponds to a definition of a 'monument' (again from the Oxford English Dictionary 1964): Anything that, by its survival, commemorates a person, action, period or event. The Kruger monument in Pretoria commemorates, and undoubtedly 
celebrates, a whole history of various successive forms of resistance to oppression, and to the supremacy of white Afrikanerdom.

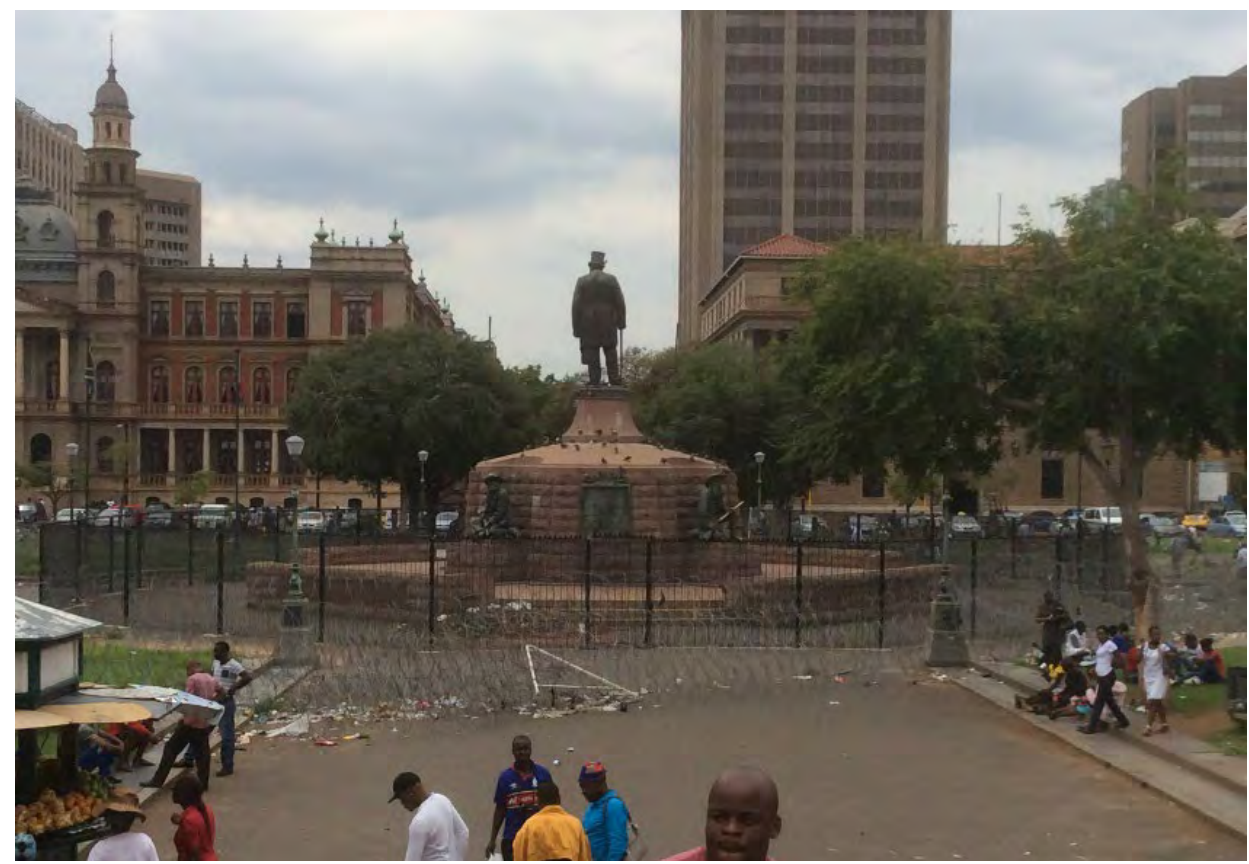

Figure 2.1 Van Wouw, Anton. Monument to Paul Kruger. [Bronze sculpture]. Church Square, Pretoria. 1896. Photograph: Anitra Nettleton, January 2016.

Yet, because it forms part of an historical narrative, and is claimed as part of partisan heritage, functioning as what Kuhn $(2010,299)$ calls a "memory text", it survives. Postulating that memory texts allow for social memory, and for an acceptance of memory as unfixed and open to interpretation, Kuhn places both narrative and performance at the centre of "memory work". The Kruger monument has thus been a pivot on which numerous pro- and antagonistic performances have revolved and according to the Mayor of Tshwane, will remain at the centre of the square as it becomes a more inclusive heritage site. The Rhodes statue, however, went largely unremarked until it became a pivot in the antagonistic and agonistic political environment of the \#RhodesMustFall movement in 2015. It formed a fulcrum for discussions about decolonialising universities, but not because of what it was (a statue in a western mode). 
Some survivals are accidental in the sense that they are not understood, as might be the case with the Miner's Statue in Johannesburg. The statue represented three miners, one white, the overseer, fully dressed and with a lamp (to lead the way), two black rock drill operators, bare to the waist and doing most of the labour. The racist overtones of this composition appear to have gone unnoticed by all - students of mine interviewing passers-by about the monument in 2004-2006, were often told that it represented men manning an anti-aircraft gun rather than a rock drill. None of the interviewees appeared to have noticed the clearly delineated differences between black and white figures in the scene. Perhaps because these are nameless individuals, because nobody really knows what they represent, and because they are not at the centre of any performances they have been ignored, except by the metal thieves who regularly manage to remove parts of sculptures or their brass plaques around the South African landscape. Such sculptures are kept as heritage, restored and re-patinated, without a clear understanding of their origins, accepted as part of a wider history and a continuously shifting net of heritage

As 'heritage' is an idea that is pivotal in the cultural politics of remembrance and of identity, it is important to unpack its nuances to establish some parameters. The Oxford English Dictionary $(1964,894)$ defines heritage as: What is or may be inherited, inherited circumstances or benefits, (fig) portion allotted to anybody. Presumably, public heritage is commonly held, but is not governed by legal documents such as the will made out by an individual. It is on the assumption of the joint ownership of what is now defined as a cultural heritage that legal systems and acts of parliament attempt to outline what may or may not be done to with or around public monuments.

Some of the issues that arise are summarised here. As against a private heritage, public heritage should be of value to all, and the value would have to be arrived at by consensus. Clearly there was consensus, in the case of the Rhodes statue at the University of Cape Town that the values that Rhodes represented were not acceptable to the majority 
of students involved in the action demanding its removal. Yet there is an argument to be made that the value of a monument may inhere in aspects other than whom it represents. Schmahmann (2016) argues that the statue, as an artwork by a woman artist, should have been accorded some degree of recognition for its aesthetic worth and its historical importance as representative of a woman's overcoming of gender biases. While this may have been extraordinary at the time of its installation in 1934, the fact of its female authorship does not render the figure any less patriarchal in its affect. It also does not exonerate those, who decided to erect the sculpture as a monument to Rhodes, from a kind of complicity in the commemoration of a now widely decried colonial master. Schmahmann's argument also acknowledges the problematics of assuming a common understanding of aesthetic value, and a common recognition of the importance of women's advancement. Neither was acknowledged in the rhetoric of the protests.

The controversy highlights that the ways in which public heritage is allotted in contemporary society has not changed very much - in the contemporary, postcolonial, polyglot African nation state, public monuments are put in place by central governments, sometimes with a nod to ethnic minorities, but more often than not, with an eye to political consequence. In such societies where social structures of the past were not homogenous, and where contemporary social structures often harden along ethnic and religious boundaries, common cultural ancestries and futures can only be imagined, to use Benedict Anderson's (1991) notion. Ultimately this political context calls into question whether there can be a "public" heritage without a centralised political control through which values and narratives are filtered. As in the past, peasants had very little say in the vested interests of the kings, so, today, the working classes have little say in the ways in which monuments are designed and constructed. The toppling of monuments of the former Soviet regime across Eastern Europe in the late 1980s and early 1990s after the fall of the Iron Curtain bears ample testimony to the ways in which people enact their power against their former oppressors (Freedberg 2012; Grant 2001). 


\section{Monuments by recognition, Art by appropriation}

There is a final ontological status for monuments that encompasses both the dimension of design and survival. Many large-scale sculptures and architectural structures are in some sort monuments, being recognised as such in the present because of their size and aesthetic content (Riegl 1982). Often their size makes them inescapable, their materials make them venerable for their age, their aesthetic dimensions of design make them pleasing or impressive to behold. Consequently, they are recognised as monuments, even though they were not built as such. Two Southern African examples of this would be Great Zimbabwe in Zimbabwe and Mapungubwe in South Africa. Both of these ancient sites rank high in the heritage hierarchies of their respective contemporary nation-states, and both provide symbols for nation-building. They are both impressive for their scale and their African lineages that are impeccably pre-colonial. They are recognised as complex structures encompassing important iconographic elements and are thus subsumed into the realm of 'art' in its broadest definition. They offer precursors for new forms of memorial such as the experiential journeys mapped out at Freedom Park in Pretoria. But they were not built as monuments or as memorials. They have only become such in the context of debates about African heritage from colonial times onwards, and thus draw on theoretical paradigms such as that propounded by Riegl (1982). In this context, however, their significance has been made "African" by being extrapolated from their original ethnic connections to continental significance.

\section{The particular problem of effigies}

Number 4 of the Oxford English Dictionary definitions of "monument" cited above specifically mentions "effigies" as constituting a form of monument (Oxford English Dictionary 1964 1278). An effigy is essentially a figurative representation of a dead person (sometimes also a dog or a horse), which should be recognisable as a particular person 
(or animal). Effigies were originally attached to tombs of deceased members of the European aristocracy. In this an effigy is different from a 'portrait', which is generally identified as a likeness of a person, the sitter, 'taken' by the artist during the sitter's lifetime (Brillliant 1974). But while neither the effigy nor the portrait is considered as a monument unless so constituted in a public space, the representational image as a portrait is often central to the commemoration of the person, and sometimes of a specific event with which the actor is associated. Freedberg has argued that the power of images centres on "... the assumption of presence - what is represented becomes fully present - the sign becomes living embodiment of what it signifies." (Freedberg 1989, 28). It appears to have been this assumption of presence that underlay the reactions of students to the images of Rhodes and others at UCT during the \#RhodesMustfFall campaign and protests of 2015/2016, but is barely discussed in any of the articles that have covered this specific debate, which is central to the discussion in some of the essays in this book.

It is interesting that it is precisely this power of attraction exercised by the likeness of the effigy or portrait (real or imaginary) of historical personages that has governed the kind of monuments that have been erected in post-apartheid South Africa and in many postcolonial African states. In the latter, one of the favoured modes is that of a stark socialist realism espoused by Chinese and North Korean monument makers who execute commissions for African states from Zimbabwe, and Senegal, through Republic of Benin, in the Democratic Republic of Congo, Namibia and Botswana (Arnold 1989; Kirkwood 2013). Furthermore, the monumental is often here completely aligned with the colossal, the size of the figure deliberately dwarfing the viewer, so that the obsequies paid and performed by those in the vicinity is physically inescapable and psychologically disturbing. While South Africa has descended to similarly aesthetically barren statements, in statues to Nelson Mandela at Sandton Square (Sandton) and the Union Buildings (Pretoria), these are homegrown variants, many of them made to 'match' existing apartheid monuments. These stratagems seem to be 
adopted on the assumption that heritage divisions could be solved, simply by adding more effigies to an already overcrowded, almost entirely male-dominated space of public commemoration.

On a visit to Pretoria/Tshwane in late April 2015, to consider the present state of the Kruger Monument in Church Street, I spent some time in Pretorius Square in front of the Pretoria City Hall where another example of such accretion of monuments is visible. Here large-scale monuments to Andries Pretorius (an equestrian sculpture) (Figure 2.2) after whom Pretoria was named, and his son Marthinus Wessel Pretorius (a standing male figure with a book prominent in his hand) have stood as symbols of the ascendance of white nationalism since the 1940s (Figure 2.3). Both figures, made by Coert Steynberg and unveiled in 1945, are unmistakably 'western' because dressed in trousers and shirts and hats and shoes, with beards and 'European' facial features, in all probability having some authenticity as portraits of their subjects. A sculpture by the well-known contemporary sculptor, Angus Taylor, representing Chief Tshwane, after whom the greater metropole takes its new name, joined the older pair in 2006 (Figure 2.4). This larger than life figure of a contested historical/mythological African indigene stands in the rear of a procession from the doors of the city hall towards the street. Tshwane is positioned therefore furthest away from those approaching from the street, and although on a higher base than the others, remains dwarfed by the equestrian figure and behind both white men. 


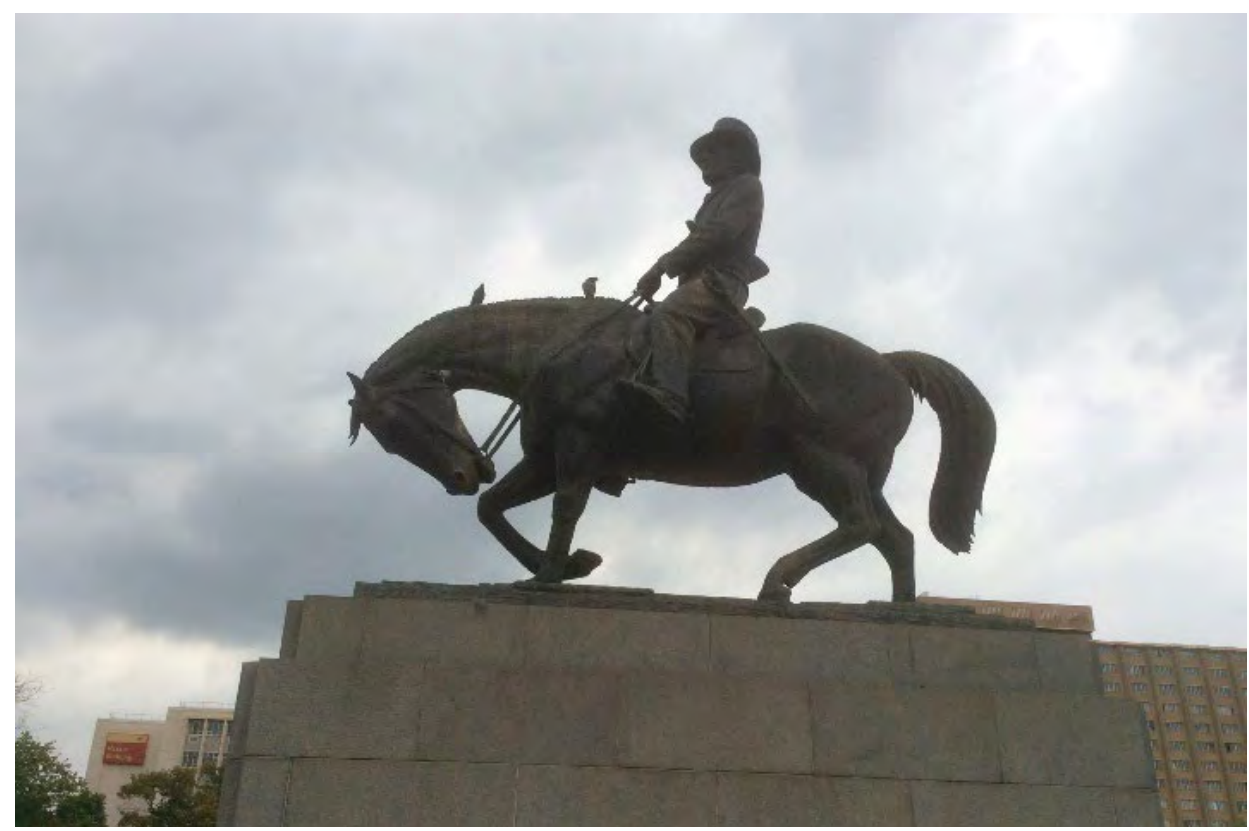

Figure 2.2 Steynberg, Coert. Andries Pretorius. [Bronze sculpture]. Pretorius Square, Pretoria. 1945. Photograph: Anitra Nettleton, January 2016

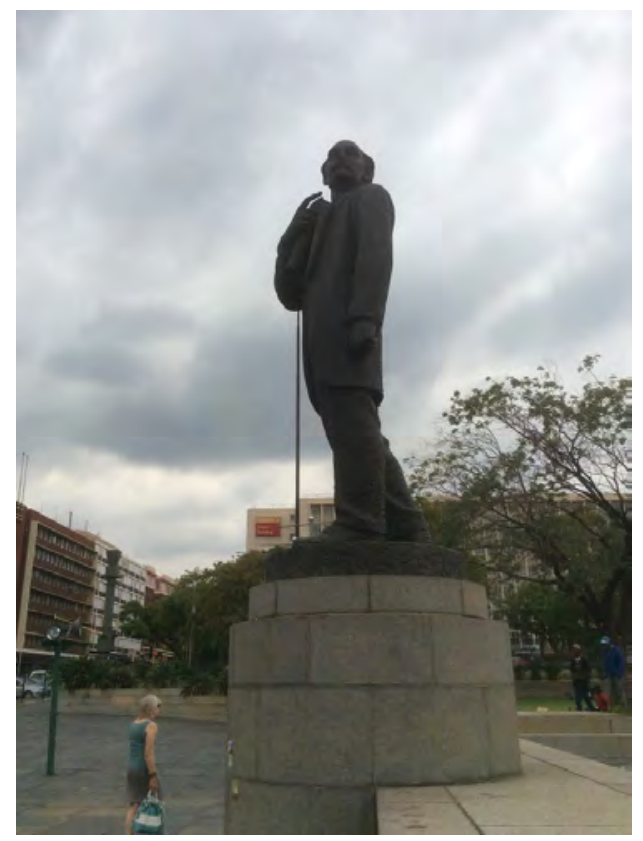

Figure 2.3. Steynberg, Coert. Marthinus Wessels Pretorius. [Bronze sculpture]. Pretorius Square, Pretoria City, Tshwane. 1945. Photograph: Anitra Nettleton, January 2016 

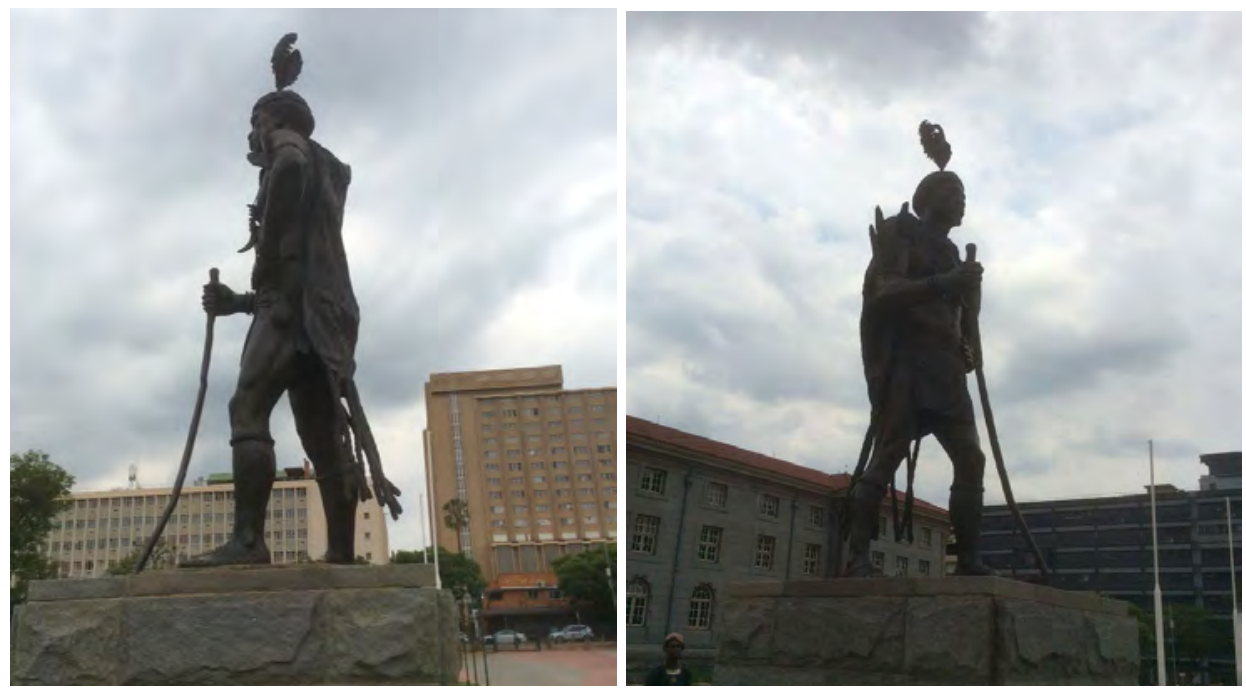

Figures 2.4. \& 2.5. Chief Tshwane. [Bronze sculpture]. Pretorius Square, Pretoria City, Tshwane. Photograph: Anitra Nettleton, January 2016

The figure of chief Tshwane is equal in size to the two Afrikaner Boer heroes - also made in bronze, but dressed in indigenous African attire, comprised largely of skins covering the loins with long dreadlocks and other hair adornments. In all, the figure appears as a reconstruction based on anthropological accounts of indigenous customs and the artist's idea of an heroic African indigene. In fact, it could have been copied out of a $1^{\text {th }}$ century illustration of indigenous South African warriors whom the colonists depicted as a form of 'noble savage' (Klopper 1992; Nettleton 2017). That there is some question as to the exact genealogical origins of this personage - most likely he was a descendent of a Zulu chief, Muzi, who had migrated to the area from Natal, and was thus a leader of a group identified as Manala Ndebele. ${ }^{1}$ Given that the identification of this character remains speculative, the monument itself must be more than usually visually speculative.

When I asked, few of the local visitors to the space occupied by the figures (used by a local photographer as a backdrop for the portraits he

$1 \quad$ See a history of Ndebele in this area by Peter Delius (1987) - although there is no mention of Tshwane per se, it is clear that Nguni-speakers, Ndebele, had lived in the area prior to white settlement. 
makes for paying customers) had any idea of whom any of the figures represented, their identifying brass plaques having been stolen. Most considered the African figure to be 'Shaka', because he was wearing what they thought were "Zulu" clothes. That there is little to differentiate this figure from another bronze sculpture, erected at Ondini Museum to commemorate King Cetshwayo Ka Mpande, clearly points to a form of iconological and visual mythologising that is elective, selective and thus flattens histories. ${ }^{2}$ The onlookers' misidentification of Tshwane is possibly also a result of Shaka's being the only great culture hero of South African history with whom they are familiar from school - and this in a city occupied largely by SothoTswana speakers. Only the resident park photographer knew that it was Chief Tshwane. The difference between the European and the African in these figures rests only on the style of dress of and possibly in their facial features, but is not visible not in their colour, because the tradition of uncoloured, naturally patinated, bronze (or marble) as a medium flattens out the racial marker of skin pigmentation. The reliance purely on renderings of detail to indicate differences of identity demonstrates the degree to which a realistic style of representation has become an apparently essential requirement for such sculptures. It may also explain the popularity of realism as a style of representation - often of varying degrees of competence - for use in contemporary monuments.

Although the Korean/Chinese social-realist style, used in the contemporary monuments made for many other African states, is both more dogmatic, more militaristic in its hard-edged-ness, it is, ironically, very similar in intention to the monumental sculptures erected within apartheid South Africa, by the apartheid regime (e.g. the now imploded Strijdom Head in Pretoria). ${ }^{3}$ And, of course, the style is part of the

2 It is interesting that this mode is reserved only for leaders of the mythological past. The sculpture of Chief Albert Luthuli, Nobel Peace laureate, in KwaDukuza, shows him as a dapper man in western-style suit with hat and walking cane. He has no African accoutrements such as those he wore to the award ceremony for the Nobel Prize. Thanks to Juliette Leeb-du Toit for bringing this fact to my attention.

3 Examples include the Head of Strijdom which mysteriously "collapsed" on 31 $1^{\text {st }}$ May, 2001 into a parking garage below Strijdom Square in Pretoria, to the large sculpture of 
content, part of the meaning, as is the scale. To make a monument on a huge scale and in a realist style associated with fascist regimes such as Hitler's and Mussolini's, no less than Stalin's, is not an innocent act. It is an act impregnated with ideological assumptions in which (purportedly western) realism is foregrounded as the most advanced, the most progressive stylistic choice. This ideology, which presents distortion and abstraction as "child-like" and "primitive", is visible in the tracts written by western anthropologists on so-called "primitive" cultures and their arts, and in the attitudes of those who came to appreciate third-world arts precisely because they had not fallen prey to the allure of realism or mimesis. Most significantly, however, it is also evident in the kinds of sculptural monuments being erected to commemorate leaders of emergent African nations who are looking for a modern identity. ${ }^{4}$

Probably the ideological arguments for Socialist-Realist monuments would follow this trajectory: Monuments are erected for the people and so they are commissioned by the peoples' representatives in styles and forms that cater to the expectations, the tastes, the levels of understanding of the "people". ${ }^{5}$ It is probably true that most people expect monuments to be representational/recognisable figurative sculptures that are seriously sombre. ${ }^{6}$ Those anti-monuments, or conceptual monuments which have slipped through the noose, especially in South Africa, have generally, like the Women's Monument in the Union Buildings in Pretoria, met with mixed, if not lukewarm reactions from the public or the powers-that-be (Becker 2000). The extraordinary success of the poetic figuration achieved by Marco

Verwoerd in Bloemfontein, removed from its plinth and placed in the Afrikaner stronghold of Orania. See Coombes (2003) for a discussion of some of these issues.

4 The idea that African art traditions were worthy of imitation and emulation by contemporary artists was particularly a theme in Senghor's writing (Harney, 2004) and was echoed by others such as Enwonwu (Ogbechi, 2008). But it is not a proposition that has found much resonance with those who have the power to commission national monuments. See Maselela (2016) for a critique of Senghor and cultural assimilation in postcolonial African contexts.

5 See King (1998) for a discussion of such processes in relation to the erection of war memorials in Britain

6 See Swedberg (2005) for a discussion of the mismatch between the history/mythology of the Burghers of Calais and the actual historical records, and the lack of impact this has had on an understanding of Rodin's famous Burghers of Calais of 1889. 
Cianfanelli in the monument to Nelson Mandela at the so-called 'capture site' at Howick in KwaZulu-Natal, goes against this trend. It is testament to the fact that one does not have to indulge in the kind of neo-romantic realism of bronze figure sculpture that seems to be in vogue amongst political commissars such as Dali Tambo in dealing with the monumental commemoration of members of the liberation struggle and its deeper history. While such realism might give the impression of these being 'portraits' of real people, their historical status is based on an appeal to a collective memory possibly embedded within the sculptural portrayal.

This can be illustrated in the monument recently erected at the "capture site" of Jacob Zuma in Groot Marico, set up in apparent emulation of, if not in competition with that of Nelson Mandela. Originally conceived as a 6 meter tall bronze sculpture (portrait) of the former president of the Republic, this idea was scrapped to be replaced by a cut-out portrait bust against a light-containing sphere, supported on a stand of multiple stainless steel arcs, also standing 6 meters tall. Interestingly the portrait only becomes fully legible once it is lit up at night. In this, and in its scale and elevation, it certainly vies for attention with billboard advertising; similarly to these it lacks any of the sense of interaction with the landscape, of becoming and dissolving, features delicately handled in Cianfanelli's Mandela monument in Howick. Its commercial qualities have seen it likened on social media to the trophy use for the Football World Cup. This is possibly explained by the fact that the artist, Chris van der Vyver, is a boilermaker by trade, and made the sculpture on winning the commission. Reaction to the sculpture/monument has been largely mixed: although the artist is reported to be very pleased with it ${ }^{7}$. and Jacob Zuma was all smiles at its unveiling, many commentators have been critical. $^{8}$ https://www.pressreader.com/south-africa/sowetan/20171006/281479276624718 accessed 20171109.

8 See for example the twitter feed responses to Tshehle, B. "In Pictures: Residents divided over R1.8 million Jacob Zuma Monument." Sunday Times: Times Live https://www. timeslive.co.za/politics/2017-10-05-in-pictures--residents-divided-over-r18-millionjacob-zuma-monument/ accessed 20171109 
South Africa deserves better forms of commemoration. It has the artists, the conceptual capacity and the technical ability to make a more significant, thoughtful, and Africa-centred and Africa-inspired memorials, than tired remakes of colonial prototypes. Our narratives are varied and, when shared, our remembering is often fractured and fractious, but the tendency in making monuments seems to be to try to make a fairy tale past visible in a flattened notion of "Africa", whether historical or contemporary, by using styles and genres of representation that are tired and tied to essentially non-democratic institutions.

\section{Bibliography}

Anderson, Benedict.

Imagined Communities: Reflections on the origin and spread of Nationalism. London: Verso, 1991.

Arnold, Mary.

"A Change of Regime: Art and Ideology in Rhodesia and Zimbabwe." In African Art from Southern Africa: from Tradition to Township, edited by Anitra C. E. Nettleton, William David Hammond-Tooke, 1172-1190. Johannesburg: Donker, 1989.

Becker, Rayda.

"The New Monument to the women of South Africa." African Arts, 33, no. 4 (2000):1,4,6,8,9.

Blier, Suzanne Preston.

Royal Arts of Africa: The majesty of form. London: Laurence King, 1998.

Brilliant, Richard.

Roman Art: From the Republic to Constantine. London: Phaidon, 1974.

Calhoun, Craig.

"Introduction: Habermas and the Public Sphere." In Habermas and the Public Sphere, edited by Craig Calhoun. Cambridge: MIT Press, 1992.

Cavanagh, Terry.

Public Sculpture of Liverpool. Liverpool: Liverpool University Press, 1996.

Coombes, Annie E.

History after apartheid: Visual culture and public memory in a democratic South Africa. Durham: Duke University Press, 2003. 
Coutu, Joan.

Persuasion and Propaganda Monuments and the Eighteenth-century British Empire. Montreal \& Kingston: McGill-Queen's University Press, 2006.

De Grunne, Bernard.

Djenné-Jeno: 1000 Years of Terracotta Statuary in Mali. Brussels, Mercatorfonds and London: Yale University Press, 2014.

Delius, Peter.

The Ndundza Ndebele: Indenture and the making of ethnic identity. History Workshop, University of the Witwatersrand, 1989. Accessed 11 September 2017, http://wiredspace.wits.ac.za/bitstream/handle/10539/7782/HWS-91. pdf?sequence=1\&isAllowed $=y$

Elsen, Albert.

Rodin. New York: The Museum of Modern Art. 1967.

Forster, Kurt W.

"Monument and memory and the mortality of Architecture." In Oppositions Reader: Selected readings from a journal for ideas and criticism in architecture 1973-1984, edited by K. Michael Hays, 18-35. New York: Princeton Architectural Press, 1989.

Freedberg, David.

The Power of Images: Studies in the history and theory of response. Chicago: University of Chicago Press, 1989.

Freedberg, David.

"The case of The Spear." Art South Africa 11, no. 1(2012): 36-41.

Gamboni, Dario.

The Destruction of Art: Iconoclasm and vandalism since the French Revolution.

Boston: Yale University Press and London: Reaktion Books, 1997.

Grant, Bruce.

"New Mosecow monuments, or, states of innocence." American Ethnologist 28, no. 2(2001): 332-362.

Habermas, Jürgen.

The Structural Transformation of the Public Sphere: An inquiry into a category of bourgeois society. Oxford: Wiley and Polity, 1989.

Harney, Elizabeth.

In Senghor's Shadow: Art, Politics and the Avant Garde in Senegal 1960-1995.

Durham: Duke University Press, 2004. 
King, Alex.

Memorials of the great war in Britain: The symbolism and politics of remembrance (the legacy of the great War). London: Bloomsbury, 1998.

Kirkwood, Meghan L.E.

"Postindependence architecture through North Korean modes: Namibian commissions of the Mansudae Overseas Project."In A companion to contemporary African Art, edited by Gitti Salami and Monica Blackmun Visonà. Oxford: Wiley Blackwell, 2013.

Klopper, Sandra.

"A man of splendid appearance: Angas's Umtimuni, nephew of Chaka the late Zulu king." African Studies 53, no. 2(1994): 3-24.

Knapp, Steven.

"Collective Memory and the Actual Past." Representations 26 (1989): 123-149.

Kuhn, Annette.

"Memory texts and memory work: Performances of memory in and with visual media." Memory Studies 3, no. 4 (2010): 298-310.

Lamola, Malesela John.

Senghor, Globalism and Africanity. Phronimon, 17, no. 2 (2016): 51-67. Accessed 11 September 2017, http://www.scielo.org.za/pdf/phronimon/v17n2/08.pdf

Nettleton, Anitra.

"Crossing the chest: Bandoliers with and without bullets in imaging the Zulu." Southern African Humanities 30, no. 1(2017): 125-143.

Ngoepe, Karabo.

Right wing could be behind defacing of statues: Tshwane Mayor. News24, 10 July, 2015. Accessed 11 September 2017, https://www.news24.com/SouthAfrica/ News/Right-wing-could-be-behind-defacing-of-statues-Tshwanemayor-20151007

Nickel, L.

"The terracotta army." In The First Emperor: China's terracotta Army, edited by J. Portal, 159-179. London: British Museum Press, 2007.

Nora, Pierre.

"Between memory and history: Les lieux de memoire." Translated by Marc Roudebush. Representations 26 (1989):7-24. 
Osborne, Robin.

Archaic and Classical Greek Art. Oxford: Oxford University Press, 1998. Ogbechie, Sylvester Okwunodu.

Ben Enwonwu:

The making of an African modernist. Rochester, NY: University of Rochester Press, 2008.

Reynolds, Donald Martin.

"The Value of Public Monuments." In Remove not the Ancient Landmark: Public Monuments and Moral Values, edited by Donald Martin Reynolds, 59-63. London: Gordon and Breach Publishers, 1996.

Rawson, Jessica.

"The first emperor's tomb: The afterlife of the universe." In The First Emperor: China's terracotta Army, edited by Jane Portal, 115-151. London: British Museum Press, 2007.

Riegl, Alois.

"The Modern Cult of Monuments: Its Character and Its Origin." Translated by Kurt W. Forster \& Diane Ghirardo. Oppositions 25, no. 3 (1982): 21-51.

Schmahmann, Brenda.

"The Fall of Rhodes: The Removal of a Sculpture from the University of Cape Town." Public Art Dialogue 6, no. 1 (2016): 90-115. https://doi.org/10.1080/21502 552.2016 .1149391

Swedberg, Richard.

Auguste Rodin's The Burghers of Calais: The career of a sculpture and its appeal to civic heroism. Theory, Culture and Society 22, no. 2 (2005): 45-67.

Tshehle, Boitumelo.

I'm proud of my Zuma statue. Sowetan, 6 October, 2017. Accessed 11 September 2017, https://www.pressreader.com/south-africa/sowet an/20171006/281479276624718

Van der Walt, Sarel.

Paul Kruger to get new neighbours at Pretoria's Church Square. News24, 19 May, 2017. Accessed 11 September 2017, https://www.news24.com/SouthAfrica/News/ paul-kruger-to-get-new-neighbours-at-pretorias-church-square-20170519 